\title{
DE VERBIZONDERING DER CAPACITEITSKOSTEN IN BEDRIJVEN MET SEIZOENPRODUKTIE
}

\author{
door J. Winselaar
}

\section{Inleiding}

Het probleem van de verbizondering der capaciteitskosten in bedrijven met seizoenproduktie wordt door Prof. Dr. H. J. van der Schroeff zeer uitvoerig behandeld in hoofdstuk $\mathrm{X}$ van de eerste druk van zijn boek „De Leer van de Kostprijs". Indien de mogelijkheid van voorraadvorming niet aanwezig is en de produktie onafhankelijk is van het jaargetijde, zijn het volgens Prof. van der Schroeff de afnemers, die door de ongelijkmatigheid van hun vraag een overcapaciteit doen ontstaan. Bij de oplossing van het vraagstuk van de verbizondering der capaciteitskosten zal in dit geval dus moeten worden vastgesteld, welke afnemers, c.q. groepen van afnemers voor deze kosten verantwoordelijk zijn en in welke mate. Om de grondslagen vast te stellen, volgens welke de capaciteitskosten moeten worden verbizonderd, is dan ook door hem de structuur van de afzet geanalyseerd.

Aangezien deze analyse ons echter niet in alle opzichten vermag te bevredigen, zal in deze beschouwing een poging worden gedaan om onze bezwaren tegen de door Prof. van der Schroeff ontwikkelde gedachtengang naar voren te brengen, terwijl tevens van de gelegenheid gebruik zal worden gemaakt om onze eigen inzichten met betrekking tot deze materie, althans voor zover deze af wijken van die van Prof. van der Schroeff, kenbaar te maken.

In dit verband is het van belang eerst in beknopte vorm de door Prof. van der Schroeff inzake bovengenoemd onderwerp gehuldigde opvattingen weer te geven.

\section{De theorie van Prof. van der Schroeff}

De eenvoudigste structuur van seizoenafzet is die, waarbij de schommeling ontstaat door de verhoogde vraag in het seizoen van afnemers, die ook geregeld buiten het seizoen de goederen van het bedrijf betrekken of van de door het bedrijf bewezen diensten gebruik maken. Voor dat geval kan men zeggen, dat alle afnemers door hun meerdere vraag in het seizoen de overcapaciteit doen ontstaan en allen derhalve voor de kosten van de overcapaciteit aansprakelijk zijn. De capaciteitskosten en ook de kosten van de overcapaciteit moeten in organische samenhang worden gezien met het totaal der geproduceerde eenheden, zowel met die, welke in het seizoen, als die, welke daarbuiten zijn voortgebracht.

Zodra er echter meerdere groepen van afnemers zijn, die in en buiten het seizoen verschillende hoeveelheden afnemen, zal bovenstaande methode niet meer kunnen worden toegepast. Voor de analyse van dit geval bedient Prof. van der Schroeff zich van het volgende voorbeeld.

Hij denkt zich een bedrijf met een seizoenafzet, dat over een produktiecapaciteit beschikt, waarmede bij volle bezetting 10.000 produkteenheden per maand kunnen worden voortgebracht. De capaciteitskosten bedragen $f 120.000,--$ per jaar. Doordat voorraadvorming niet mogelijk is, zetten de seizoenfluctuaties in de afzet zich in de produktie voort. Gedurende de seizoentijd, die op 4 maanden 
wordt gesteld, wordt om aan de vraag te voldoen de beschikbare gelijktijdelijke capaciteit van het bedrijf ten volle in beslag genomen en worden derhalve 10.000 eenheden per maand geproduceerd. In het overige deel van het jaar is de afzet slechts 5.000 eenheden per maand en wordt dan ook dit aantal eenheden voortgebracht. Het produktiediagram van dit bedrijf wordt aangegeven door figuur 1 .

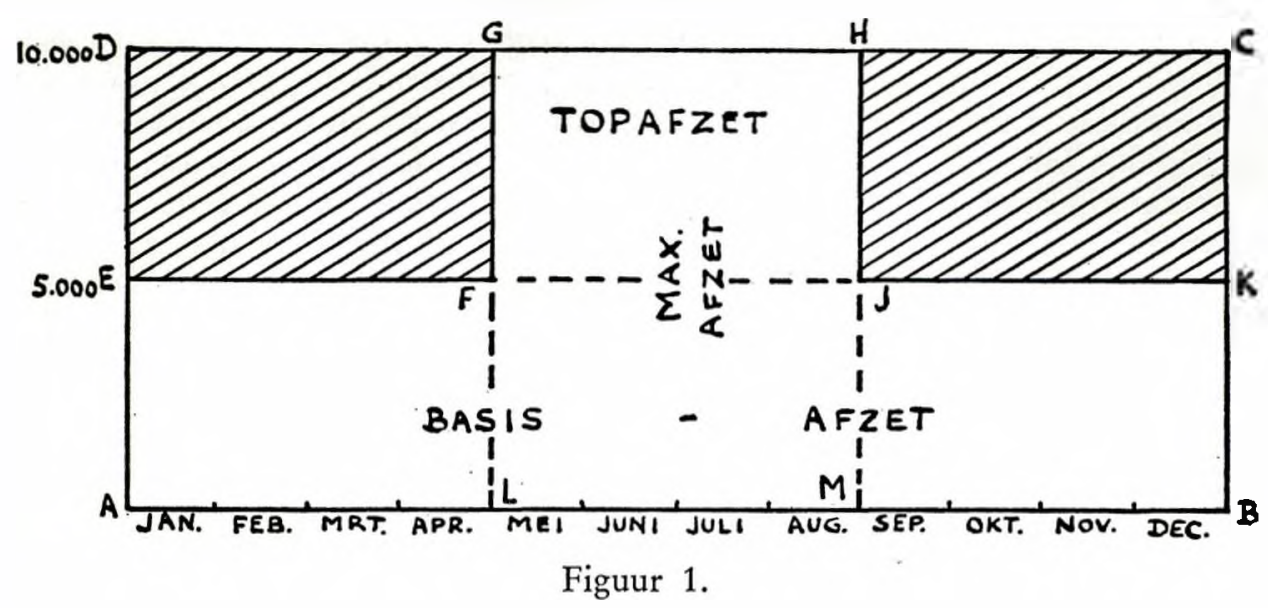

In dit diagram wordt de bezetting van de beschikbare produktiecapaciteit aangegeven door de getrokken lijn; het gearceerde gedeelte geeft de overcapaciteit aan. De figuur beeldt tevens de omvang van de afzet in de verschillende perioden van het jaar uit. Het deel van de afzet, aangegeven door de letters GFJH wordt aangeduid met de term topafzet, het deel ABKE met basisafzet en het deel GLMH met de term maximumafzet. Aangezien in dit voorbeeld produktie en afzet in de perioden van de seizoencyclus gelijke tred houden, kan de hierboven gemaakte onderscheiding ook worden toegepast op de produktie. Zo onderscheidt Prof. van der Schroeff dan ook top-, basis- en maximumproduktie.

Ten opzichte van de oorzakelijke betrekking tussen afzet (c.q. produktie) en overcapaciteit laten zich 3 mogelijkheden denken. De kritische oorzaak van het ontstaan van de overcapaciteit kan namelijk worden gezocht bij:

1. de topafzet;

2. de maximumafzet;

3. de basis- èn de topafzer (dus de totale afzet).

Prof. van der Schroeff gaat daarna over tot de analyse van deze 3 mogelijkheden.

Hij komt daarbij tot de conclusie, dat de topafzet dan alleen als kritische oorzaak voor het ontstaan van de overcapaciteit kan worden aangemerkt, indien er geen organische samenhang is tussen basis- en topafzet. Bestaat die samenhang wel, hetgeen meestal het geval zal zijn, dan zouden de basis- en de topafzet (dus de gehele afzet) als kritische oorzaak voor het ontstaan van de overcapaciteit moeten worden aangemerkt. Volgens Prof. van der Schroeff zal in het merendeel van de gevallen de topafzet, doordat deze met de basisafzet samenhangt, niet als op zich zelf staand mogen worden beschouwd. Dit zou volgens hem alleen mogelijk zijn, indien de topproduktie betrekking heeft op de voortbrenging van 
andere goederen of het verlenen van andere diensten dan die van de basisproduktie en geen verwantschap in produktie of samenhang in afzet tussen deze goederen en diensten aanwezig is. Een dergelijke structuur van de afzet en de produktie komt in de praktijk weinig voor en de gevallen, waarin de kosten van de overcapaciteit over de topproduktie kunnen worden verbizonderd, zouden volgens de hooggeleerde schrijver dan ook tot de uitzonderingen behoren.

De wijze van verbizondering, waarbij de afzet in het seizoen (d.i. de maximumafzet) als kritische oorzaak voor het ontstaan van de overcapaciteit wordt aangemerkt, kan worden toegepast, indien de afzet (en daarmede de produktie) buiten het seizoen een incidenteel karakter draagt. Indien aan deze voorwaarde niet voldaan is, ziet Prof. van der Schroeff als kernbezwaar tegen dit systeem van verbizondering, dat hierbij ten onrechte het incidentele beslag, dat door de afnemer op de maximumcapaciteit wordt gelegd, als maatstaf voor de verbizondering wordt aangenornen. Het toevallige verbruik op het moment van de maximum bedrijfsbezetting is volgens hem voor de verbizondering echter niet relevant; gelet zal er op moeten worden, hoe de afnemer door het verloop van zijn vraag de capaciteitskosten beïnvloedt en daardoor aansprakelijk is voor de kosten van de overcapaciteit. Daarbij zou niet alleen de grootte van de maximumvraag der afnemers van betekenis zijn, maar ook het tijdstip, waarop dit maximummoment in de vraag zich voordoet. Om de invloed van de volgtijdelijke verscheidenheid t.a.v. het maximumverbruik van de afnemers tot uitdrukking te brengen is men er toe gekomen om bij de verbizondering van de capaciteitskosten rekening te houden met de verscheidenheidsfactor. Daarbij belast men de afnemers niet naar hun beslag op de produktiecapaciteit ten tijde van de maximale belasting van de produktie-installatie, maar in verhouding van de individuele maxima van hun vraag. Op deze wijze wordt bij de verbizondering van de kosten zowel de omvang van het maximumbeslag van ieder der afnemers tot uitdrukking gebracht, als de invloed van de verscheidenheidsfactor op de kostprijs per beschikbaar gestelde produktieeenheid. Volgens Prof. van der Schroeff blijft tegen deze methode een bedenking bestaan, omdat daarin niet met de diversiteit in de duur van het beslag op de produktiecapaciteit rekening wordt gehouden. Volgens Prof. van der Schroeff moet bij de verbizondering echter rekening worden gehouden zowel met de omvang als met de duur van het beslag op de capaciteit. In het volgende onderdeel van deze beschouwing zullen we volop gelegenheid krijgen om nader in te gaan op de wijze, waarop dit probleem door Prof. van der Schroeff wordt geanalyseerd en uitgewerkt.

Tenslotte wordt het voorgaande samengevat in de conclusie, dat ieder van de afnemers de kosten moet dragen van de door hem afgenomen eenheden, vermeerderd met een aandeel in de kosten van de overcapaciteit in verhouding van hun beslag op de capaciteit op het tijdstip van de maximale belasting.

Kritische beschouwingen van de door Prof. van der Schroeff ontwikkelde theorie Evenals het elektriciteitsbedrijf is ook het gasbedrijf een prachtig voorbeeld van een bedrijf met seizoenafzet en daaraan gekoppelde seizoenproduktie. Naar de structuur van de afzet kan de gasafgifte als volgt worden onderscheiden:

a. een deel, dat betrekkelijk ongevoelig is voor temperatuurinvloeden, en waarvan de afzet vrij gelijkmatig over de maanden van het jaar verdeeld is; 
b. een deel, dat een grote gevoeligheid voor de temperatuur aan de dag legt in die zin, dat bij lage temperatuur deze afzet groot is, terwijl bij hoge temperaturen deze afzet gering is of geheel achterwege blijft.

Het gas, waarvan de afzet betrekkelijk ongevoelig is voor temperatuurinvloeden, is dat, hetwelk wordt aangewend voor huishoudelijke en industriële doeleinden. In het vervolg van deze beschouwing zullen we dit gas aanduiden als kookgas. Het gas, waarvan de afzet zeer gevoelig is voor de weersomstandigheden, is dat hetwelk wordt aangewend voor ruimteverwarming. Dit gas zullen we aanduiden als verwarmingsgas. De structuur van de gasafzet (en dus ook van de gasproduktie) bij normaal temperatuurverloop is weergegeven in figuur 2.

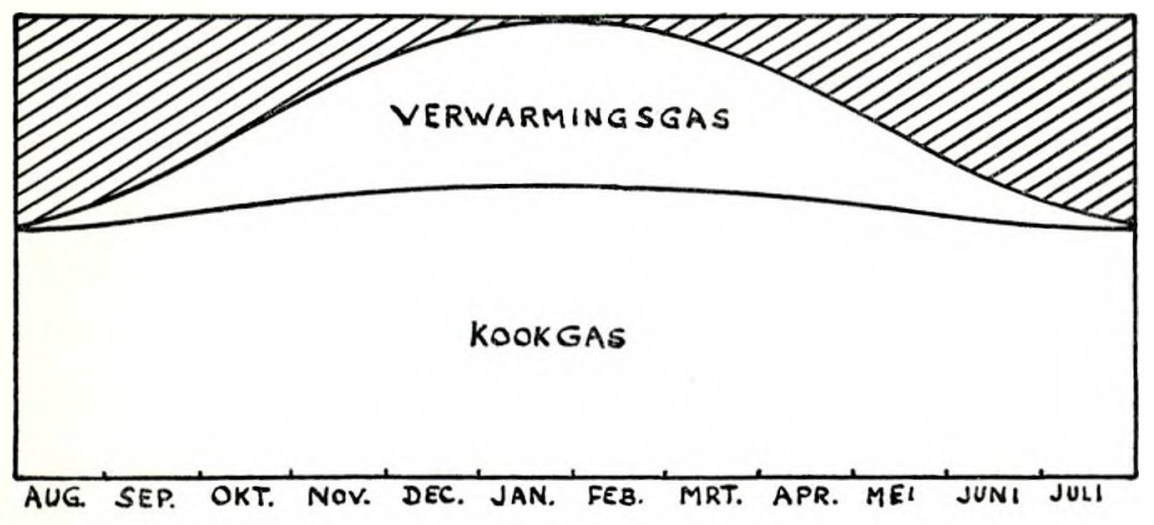

Figuur 2.

Het gearceerde gedeelte geeft in deze figuur de overcapaciteit aan.

Indien de gelijktijdelijke produktiecapaciteit op 10.000 werkeenheden per maand wordt gesteld en de capaciteitskosten op $f$ 10.000.-- per maand, kan de structuur van de gasafzet in sterk vereenvoudigde vorm worden weergegeven door figuur 3.

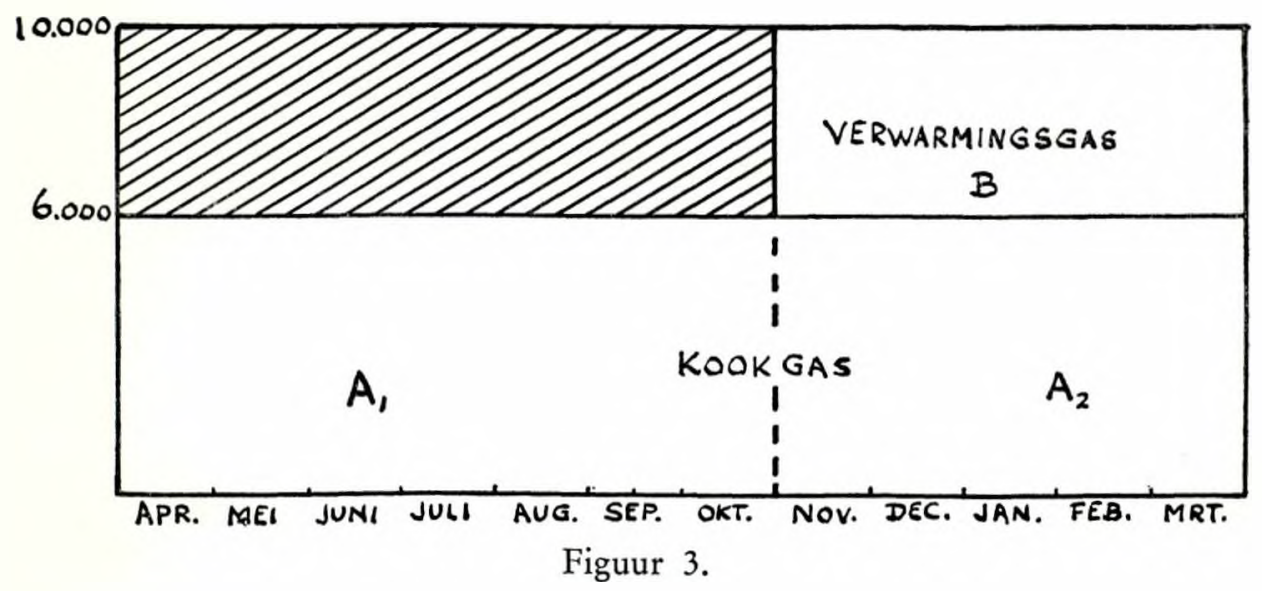

Als wij Prof. van der Schroeff goed hebben begrepen, dan zal volgens hem de kritische oorzaak van het ontstaan van de overcapaciteit in dit geval gezocht moe-

$\mathrm{m} \mathrm{a} \mathrm{b}$ blz. 316 
ten worden bij de basis- en de topafzet (dus bij de totale afzet). Hij stelt namelijk, dat indien de basisafzet er niet zou zijn, ook de seizoenspits niet zou zijn voorgekomen dan wel kleiner zou zijn geweest. Hij concludeert daaruit, dat het samengaan van top- en basisafzet leidt tot de maximumbelasting van het bedrijf, hetgeen inhoudt, dat beide delen van de afzet voor de overcapaciteit en de kosten, die daarmede samenhangen, aansprakelijk zijn. Om de capaciteitskosten te verbizonderen zou derhalve de afzet van kookgas worden gesplitst in 2 gedeelten, namelijk A1 en A2, terwijl dan vermoedelijk onderstaande redenering zou worden gevolgd.

Het beslag, dat A2 en B gelijktijdig op de produktiecapaciteit leggen, veroorzaakt de volgende kosten:

Aangewende werkeenheden

Overcapaciteit

Hiervan komt ten laste van:

\begin{tabular}{|c|c|}
\hline$\left\{\begin{array}{l}20,6 \text { van } f 78.000 .-- \\
0,4 \text {. } 78.000 .-\end{array}\right.$ & $\begin{array}{l}f \text { 46.800.-- } \\
\text { 31.200.-- }\end{array}$ \\
\hline & $f$ 78.000.-- \\
\hline
\end{tabular}

$f$ 50.000.--

,28.000.--

$f$ 78.000.--

A1 draagt voor zijn beslag gedurende 7 maanden 0,6 van $f$ 70.000.-- $=f 42.000 .--$, zodat de verbizondering zou worden:

Kookgas:

$\begin{array}{ccc}\text { A1 } & f \text { 42.000.-- } & \\ \text { A2 } & " 46.800 .-- & f \text { 88.800.-- } \\ \text { Verwarmingsgas: } & & \\ & & \underline{f 120.000 .--} \\ & & \end{array}$

Prof. van der Schroeff huldigt hier, naar wij aannemen, de opvatting dat de $k$ ritische oorzaak van de overcapaciteit is gelegen in de totale afzet. Daarentegen zijn wij van mening, dat uitsluitend de topafzet, dus het verwarmingsgas, als kritische oorzaak voor de overcapaciteit moet worden aangemerkt. In tegenstelling met de opvatting van Prof. van der Schroeff menen wij namelijk te kunnen vaststellen, dat bij het wegvallen van de basisafzet toch de seizoenspits blijft bestaan. Dit blijkt duidelijk uit figuur 3. Indien de verbruikers van kookgas zouden uitvallen, zou slechts een gelijktijdelijke produktiecapaciteit van 4.000 eenheden per maand nodig zijn om te voorzien in de behoefte aan verwarmingsgas. Daar deze capaciteit slechts gedurende 5 maanden wordt gebruikt en de overige maanden van het jaar onbenut blijft, is dus de seizoenspits nog geheel aanwezig. Omgekeerd, indien de vraag naar verwarmingsgas zou wegvallen, zou kunnen worden volstaan met een gelijktijdelijke capaciteit van 6.000 eenheden per maand. Daar gedurende het gehele jaar volledig beslag op deze capaciteit wordt gelegd, zou van enige overcapaciteit geen sprake meer zijn. Door ons zou de verbizondering van de capaciteitskosten derhalve als volgt worden berekend: 
Kookgas

Verwarmingsgas
0,6 van $f$ 120.000.-- $=f$ 72.000.--

$0,4 \quad, \quad, 120.000 .--=\frac{48.000 .--}{f \frac{120.000 .--}{0}}$

Tot staving van onze zienswijze zullen we ons bedienen van het volgende voorbeeld.

We gaan weer uit van een produktie-installatie met een gelijktijdelijke produktiecapaciteit van 10.000 werkeenheden per maand. De capaciteitskosten van deze installatie kunnen gesteld worden op $f$ 120.000.-- per jaar. Aangenomen wordt, dat het bedrijf slechts 2 afnemers (of groepen van afnemers) heeft en wel: a. een afnemer A, die een gelijkmatig verbruik heeft van 5.000 werkeenheden per maand en een afnemer $B$, die alleen in december 5.000 werkeenheden afneemt. De belasting van dit bedrijf is in figuur 4 a weergegeven, waarin het gearceerde gedeelte de onbezette capaciteit per jaar aangeeft.
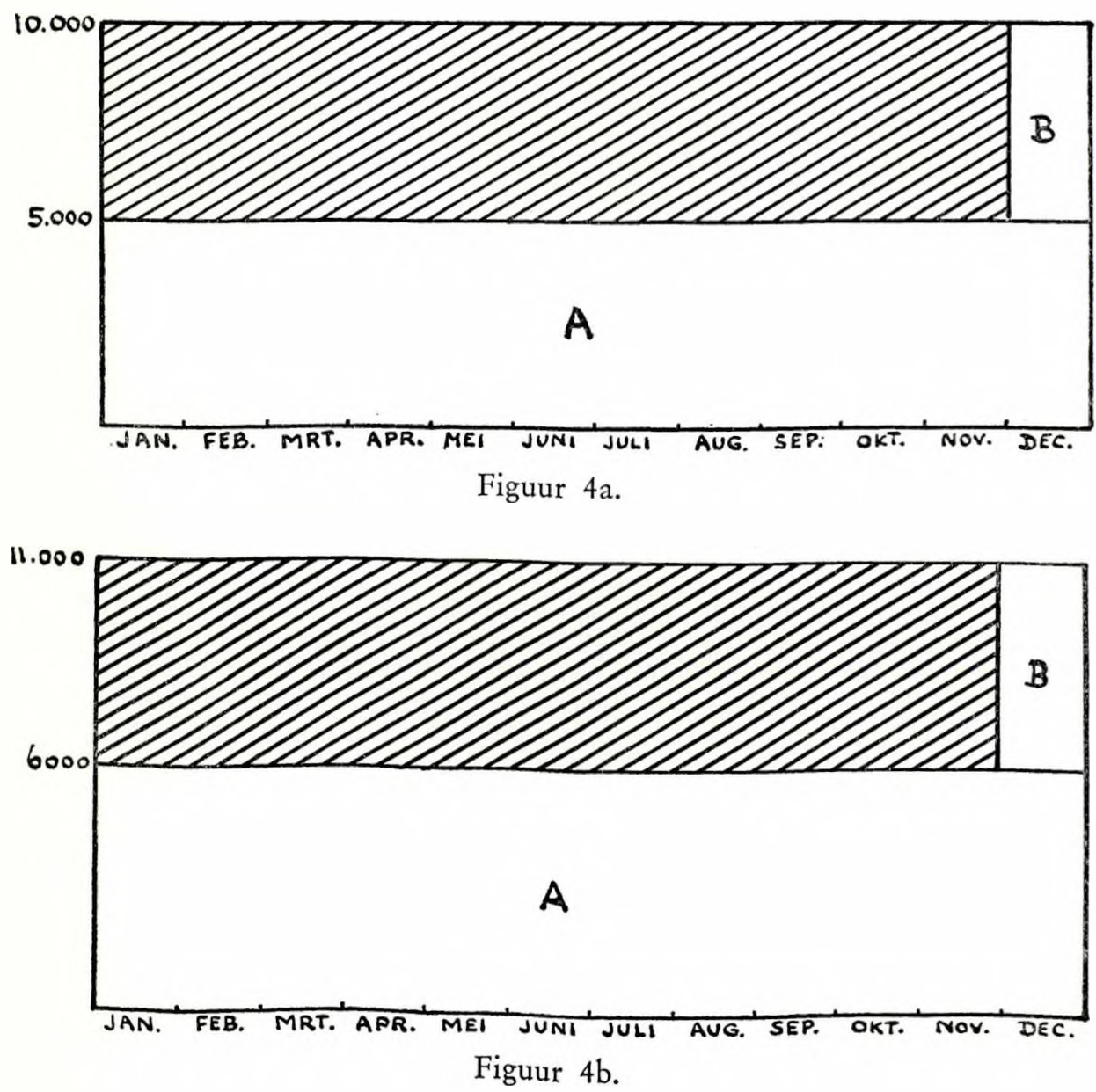

m a b blz. 318 
Het is nu van belang om na te gaan, wat de invloed op de capaciteit en daarmede op de capaciteitskosten zal zijn, indien:

b. de behoefte van $A$ toeneemt met 1.000 eenheden per maand;

c. de behoefte van $B$ in december toeneemt met 1.000 eenheden.

In beide gevallen moet de gelijktijdelijke produktiecapaciteit worden opgevoerd met 1.000 eenheden per maand, dus tot 11.000 eenheden per maand. Eenvoudigheidshalve mag hierbij worden aangenomen, dat ook de kosten in dezelfde mate zullen worden beïnvloed en dus zullen stijgen tot $1,1 \times f$ 120.000.-- $=$ $f$ 132.000.-- per jaar. Hoe de situatie door de toeneming van de vraag in de gevallen b en c zal worden, blijkt uit de figuren $4 \mathrm{~b}$ en $4 \mathrm{c}$.

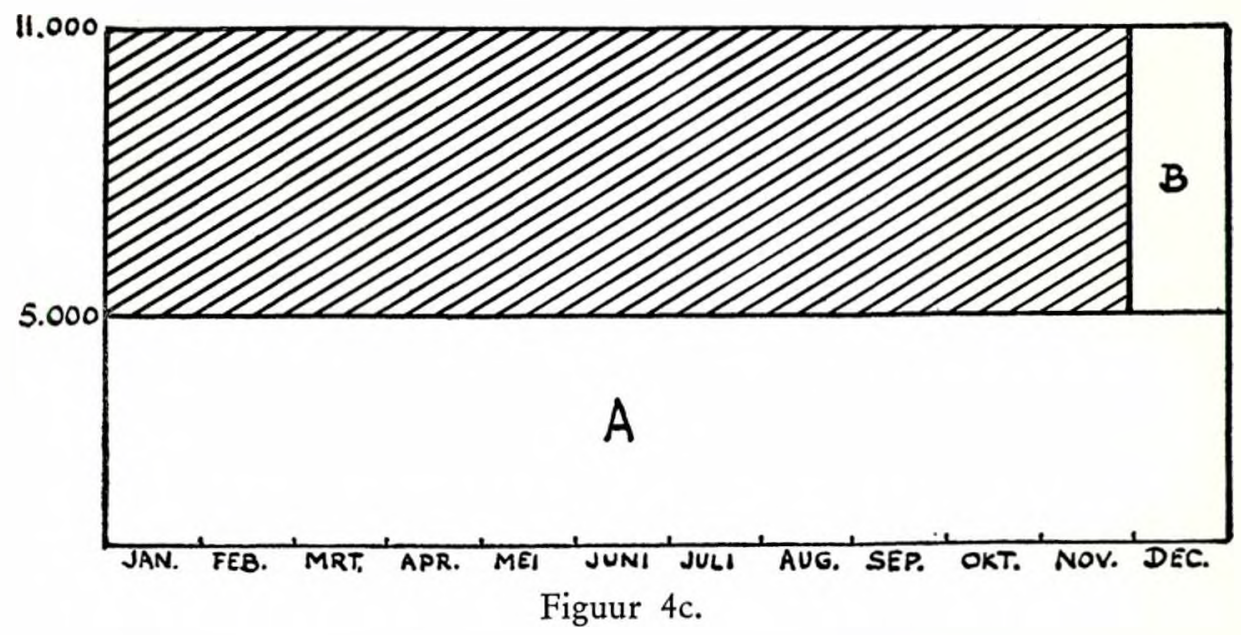

De kosten van de overcapaciteit zouden in deze 3 gevallen door Prof. van der Schroeff vermoedelijk worden verbizonderd in verhouding van het beslag, dat door de afnemers in de maand december op de capaciteit wordt gelegd. Het resultaat van deze berekening volgt hierna.

\begin{tabular}{|c|c|c|c|c|}
\hline \multirow[t]{2}{*}{ Omschrijuing } & \multicolumn{2}{|c|}{ Capaciteitskosten } & \multicolumn{2}{|c|}{$\begin{array}{c}\text { Capaciteitskoster } \\
\text { per verbruikte } \\
\text { eenheid }\end{array}$} \\
\hline & A & B & $\mathrm{A}$ & $\mathrm{B}$ \\
\hline \multirow[t]{2}{*}{$\begin{array}{l}\text { Geval a (figuur 4a): } \\
\text { Verbruikte eenheden } \\
\text { Overcapaciteit }\end{array}$} & $\begin{array}{ll}f & 60.000 .-- \\
\Rightarrow & 27.500 .-- \\
\end{array}$ & $\begin{array}{l}f \quad 5.000 .-- \\
\Rightarrow \quad 27.500 .--\end{array}$ & $\begin{array}{ll}f & 1 .-- \\
, & 0,46\end{array}$ & $\begin{array}{l}f 1 .-- \\
, 5,50 \\
\end{array}$ \\
\hline & $f \quad 87.500 .--$ & $f 32.500 .--$ & $f 1,46$ & $f \quad 6,50$ \\
\hline \multirow[t]{2}{*}{$\begin{array}{l}\text { Geval b (figuur 4b): } \\
\text { Verbruikte eenheden } \\
\text { Overcapaciteit }\end{array}$} & $\begin{array}{ll}f & 72.000 .-- \\
, & 30.000 .--\end{array}$ & $\begin{array}{l}f \quad 5.000 .-- \\
\Rightarrow 25.000 .--\end{array}$ & $\begin{array}{ll}f & 1 .-- \\
, & 0,42 \\
\end{array}$ & $\begin{array}{ll}f & 1 .-- \\
, & 5 .-- \\
\end{array}$ \\
\hline & $f$ 102.000.-- & $f 30.000 .--$ & $f 1,42$ & $f$ 6.-- \\
\hline \multirow[t]{2}{*}{$\begin{array}{l}\text { Geval c (figuur 4c): } \\
\text { Verbruikte eenheden } \\
\text { Overcapaciteit }\end{array}$} & $\begin{array}{ll}f & 60.000 .-- \\
, & 30.000 .--\end{array}$ & $\begin{array}{lr}f & 6.000 .-- \\
" & 36.000 .--\end{array}$ & $\begin{array}{ll}f & 1 .-- \\
, & 0,50\end{array}$ & $\begin{array}{ll}f & 1 .-- \\
\# & 6 .-- \\
\end{array}$ \\
\hline & $f \quad 90.000 .--$ & $f$ 42.000.-- & $f 1,50$ & $f 7 .--$ \\
\hline
\end{tabular}


Naar onze mening zouden de kosten van de overcapaciteit echter geheel ten laste van verbruiker $B$ moeten worden gebracht, waardoor dit vraagstuk als volgt zou worden opgelost.

\begin{tabular}{|c|c|c|c|c|}
\hline \multirow[t]{2}{*}{ Omschrijving } & \multicolumn{2}{|c|}{ Capaciteitskosten } & \multicolumn{2}{|c|}{$\begin{array}{c}\text { Capaciteitskosten } \\
\text { per verbruikte } \\
\text { eenbeid }\end{array}$} \\
\hline & A & B & A & $\mathrm{B}$ \\
\hline \multirow[t]{2}{*}{$\begin{array}{l}\text { Geval a: } \\
\text { Verbruikte eenheden } \\
\text { Overcapaciteit }\end{array}$} & $f$ 60.000.-- & $\begin{array}{lr}f & 5.000 .-- \\
\Rightarrow & 55.000 .--\end{array}$ & $f$ 1.-- & $\begin{array}{lr}f & 1 .-- \\
\# & 11 .-- \\
\end{array}$ \\
\hline & $f$ 60.000.-- & $f$ 60.000.-- & $f$ 1.-- & $f$ 12.-- \\
\hline \multirow[t]{2}{*}{$\begin{array}{l}\text { Geval b: } \\
\text { Verbruikte eenheden } \\
\text { Overcapaciteit }\end{array}$} & $f 72.000 .--$ & $\begin{array}{lr}f & 5.000 .-- \\
& 55.000 .-\end{array}$ & $f$ 1.-- & $\mid \begin{array}{rr}f & 1 .-- \\
, & 11 .--\end{array}$ \\
\hline & $f 72.000 .--$ & $f$ 60.000.-- & $f$ 1.-- & $f$ 12.-- \\
\hline \multirow[t]{2}{*}{$\begin{array}{l}\text { Geval c: } \\
\text { Verbruikte eenheden } \\
\text { Overcapaciteit }\end{array}$} & $f$ 60.000.-- & $\begin{array}{lr}f \quad 6.000 .-- \\
, \quad 66.000 .--\end{array}$ & $f 1 .--$ & $\begin{array}{lr}f & 1 .-- \\
\Rightarrow & 11 .--\end{array}$ \\
\hline & $f 60.000 .--$ & $f 72.000 .--$ & $f$ 1.-- & $f$ 12.-- \\
\hline
\end{tabular}

Bij toepassing van de methode van Prof. van der Schroeff wijzigen zich de capaciteitskosten per verbruikte eenheid, als de verhouding in het beslag, dat door de gezamenlijke verbruikers op het tijdstip van de maximale belasting op de produktiecapaciteit wordt gelegd, zich wijzigt, ook van die verbruikers, welker afzetstructuur ongewijzigd blijft. Wij betwijfelen of dit juist is, en menen, dat de capaciteitskosten per verbruikte eenheid worden bepaald door de verhouding tussen de verbruikte capaciteit en de benodigde capaciteit. Indien de structuur van de afzet zich niet wijzigt, blijft deze verhouding ook gelijk. Bij toepassing van onze methode zijn dan ook in alle 3 gevallen de capaciteitskosten per verbruikte eenheid gelijk.

Als het gasbedrijf van Prof. van der Schroeff er een verwarmingsklant bij krijgt, waardoor tot uitbreiding van de produktie-installatie moet worden overgegaan, laat hij de kookgasklanten een deel van de hiermede samenhangende meerdere capaciteitskosten betalen. Daarentegen kan tegen de door ons berekende kostprijs de afgifte van verwarmingsgas toenemen zonder dat dit gepaard gaat met een kostprijsverhoging van het kookgas.

Naar de mening van Prof. van der Schroeff is het toevallige verbruik op het moment van de maximum bedrijfsbezetting voor de verbizondering niet relevant, doch zal er op gelet moeten worden hoe de afnemer door het verloop van zijn vraag de capaciteitskosten beïnvloedt en daardoor aansprakelijk is voor de kosten van de overcapaciteit. Met deze uitspraak kunnen wij ons volkomen verenigen. $\mathrm{Nu}$ wil Prof. van der Schroeff echter bovendien nog rekening houden met de diversiteit in de duur van het beslag op de capaciteit. En het is met betrekking tot dit punt, dat onze tweede bedenking rijst tegen zijn betoog. Het wil ons

m a b blz. 320 
namelijk voorkomen, dat de duur van het beslag in het geheel geen invloed heeft op de hoogte van de capaciteitskosten. Om dit aan te tonen, zullen we ons nog eens bedienen van het voorbeeld, dat in figuur 4 a grafisch is weergegeven.

Om aan de behoeften van A te kunnen voldoen, is een capaciteit nodig van 5.000 eenheden per maand of 60.000 eenheden per jaar. Om aan de behoeften van $B$ te kunnen voldoen, is echter eveneens een capaciteit van 5.000 eenheden per maand of 60.000 eenheden per jaar nodig. De duur van het beslag op deze capaciteit heeft daarop geen enkele invloed. Zowel A als B dienen aan capaciteitskosten te betalen $f$ 60.000.--. De capaciteitskosten van B kunnen alleen dan worden verminderd, indien nog één of meer andere verbruikers beslag leggen op de capaciteit in andere maanden dan die, waarin door B deze capaciteit wordt gebruikt. In dit geval gaat dan de verscheidenheidsfactor een rol spelen. De situatie welke dan ontstaat, kan weer het beste aan de hand van een voorbeeld worden besproken.

We gaan weer uit van een produktie-installatie met een gelijktijdelijke produktiecapaciteit van 10.000 werkeenheden per maand. De capaciteitskosten van deze installatie kunnen gesteld worden op $f$ 120.000.-- per jaar. Aangenomen wordt, dat het bedrijf slechts 2 afnemers (of groepen van afnemers) heeft en wel een afnemer $\mathrm{A}$, die gedurende de maanden januari $\mathrm{t} / \mathrm{m}$ april een gelijkmatig verbruik heeft van 10.000 werkeenheden per maand en een afnemer $B$, die gedurende de maanden november en december eveneens 10.000 eenheden per maand afneemt. De situatie bij dit bedrijf is in figuur 5 weergegeven.

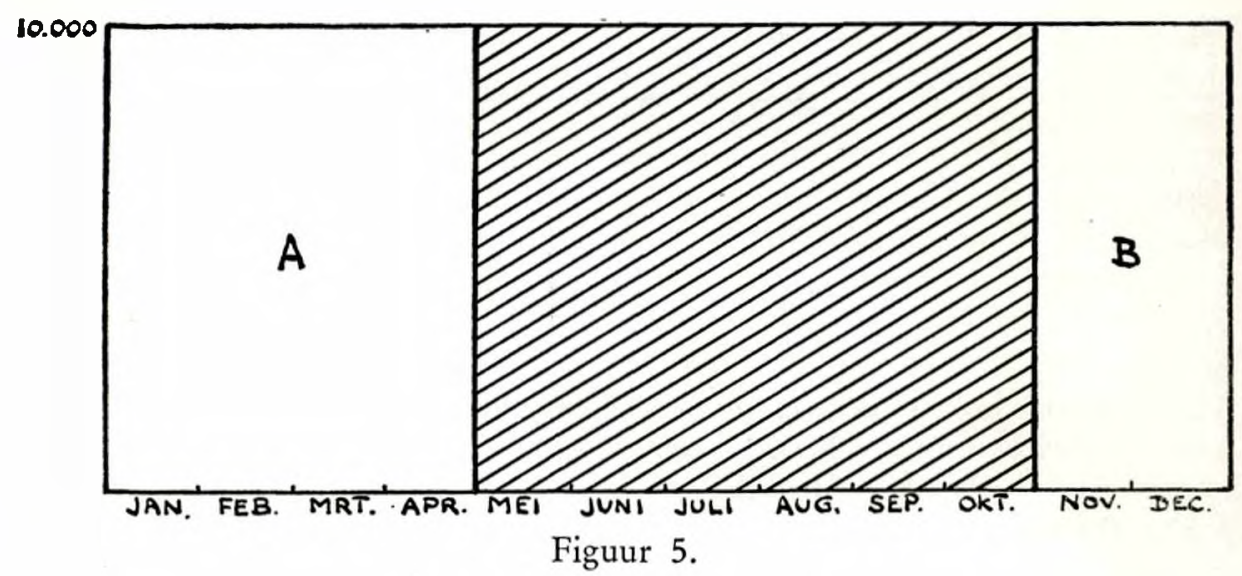

Indien A de enige afnemer was, zouden voor deze verbruiker de capaciteitskosten $f$ 120.000.-- bedragen. Voor B geldt uiteraard hetzelfde. Door de werking der verscheidenheidsfactor kunnen ze samen met een gelijktijdelijke capaciteit van 10.000 werkeenheden per maand volstaan. De vraag is nu op welke wijze de capaciteitskosten moeten worden verbizonderd.

Prof. van der Schroeff zou hier vermoedelijk tot de conclusie komen, dat de duur van het beslag op de produktiecapaciteit bepalend is voor de verbizondering van de capaciteitskosten. 
A zou dus moeten betalen en $B$

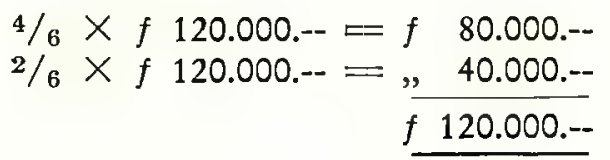

$4 / 6 \times f$ 120.000.-- $=f \quad 80.000 .--$

$f$ 120.000.--

Door de werking der verscheidenheidsfactor worden bij deze methode de capaciteitskosten van verbruiker A teruggebracht van $f$ 120.000.-- tot $f$ 80.000.--, dus tot $2 / 3$. De capaciteitskosten van verbruiker $B$ worden echter teruggebracht van $f$ 120.000.-- tot $f$ 40.000.--, dus tot $1 / 3$. Men moet zich afvragen, of dit te motiveren is.

Wanneer men zich op het standpunt stelt, dat beide verbruikers in gelijke mate dienen te profiteren van de werking der verscheidenheidsfactor, dan komt men tot de slotsom, dat ieder der verbruikers voor de helft der capaciteitskosten moet worden belast, dus ieder voor $f$ 60.000.--. Bij beide verbruikers worden dan de capaciteitskosten tot de helft teruggebracht. Hierbij dient nog te worden opgemerkt, dat toepassing van deze methode er nooit toe mag leiden, dat de capaciteitskosten per verbruikte werkeenheid lager zouden worden dan die bij volkomen gelijkmatig verbruik. In dat geval dienen deze kosten gelijk te worden gesteld aan die bij volkomen gelijkmatig verbruik. De verscheidenheidsfactor kan dan op deze kosten geen invloed meer uitoefenen.

Een derde methode, die het midden houdt tussen de beide hiervoor beschreven methoden, bestaat hierin, dat ieder der verbruikers wordt belast voor zijn verbruikte eenheden en voor de helft van de kosten van de overcapaciteit. In dit geval zou de volgende af rekening worden gemaakt.

\begin{tabular}{l||c||c}
\hline Omschrijving & $\mathrm{A}$ & $\mathrm{B}$ \\
\hline Verbruikte werkeenheden & $f 40.000 .--$ & $f 20.000 .--$ \\
Overcapaciteit $1 / 2 \times f 60.000 .--$ & $\# 30.000 .--$ & $\# 30.000 .--$ \\
Capaciteitskosten & $f 70.000 .--$ & $f 50.000 .--$ \\
\hline
\end{tabular}

Door toepassing van deze methode worden de capaciteitskosten van verbruiker A teruggebracht van $f 120.000$.-- tot $f$ 70.000.-- dus tot $7 / 12$. De capaciteitskosten van verbruiker $\mathrm{B}$ worden dan teruggebracht van $f 120.000$.-- tot $f 50.000$.--, dus tot $5 / 12$. Evenals in het eerste geval is het voordeel voor B hier groter dan voor $\mathrm{A}$.

\section{Conclusie}

Resumerend kan worden geconcludeerd, dat in bedrijven met seizoenproduktie, welke wordt veroorzaakt door meerdere groepen van afnemers, die in en buiten het seizoen verschillende hoeveelheden afnemen:

1e. de kritische oorzaak voor het bestaan van een overcapaciteit gelegen is in de topafzet, zodat de kosten van de overcapaciteit als kosten van de topafzet dienen te worden aangemerkt;

2e. de grootte van het gelijktijdelijk beslag op de produktiecapaciteit bepalend is voor de capaciteitskosten, terwijl de duur van dat beslag irrelevant is;

m a b blz. 322 
3e. door de invloed der verscheidenheidsfactor een reducerende werking op de capaciteitskosten per afnemer kan worden uitgeoefend.

\section{Naschrift}

Gaarne wil ik in een kort naschrift enige kanttekeningen maken bij de beschouwingen van de heer Winselaar, waarbij ik mij voorstel mij tot de hoofdpunten te bepalen. Ik kies deze vorm van beantwoording ten gerieve van de lezer, die thans woord en wederwoord bijeen vindt.

Ik wil voorop stellen, dat ik de bovenstaande beschouwingen met belangstelling heb gelezen, al moet ik er onmiddellijk aan toevoegen, dat de heer Winselaar mij in zijn kritische opmerkingen gedachten heeft toegeschreven, die niet mijn zienswijze weergeven. Dit geldt niet zozeer voor de korte samenvatting die schr. van mijn analyse heeft gegeven, als wel voor de interpretatie daarvan die in zijn cijfervoorbeelden tot uitdrukking komt.

Tot goed begrip van zaken zij opgemerkt, dat alhoewel de titel als onderwerp de verbijzondering van de capaciteitskosten in bedrijven met seizoen produktie aangeeft, uit het artikel blijkt dat de aandacht van de schrijver zich richt op de problematiek bij die bedrijven, die de invloed van het seizoen in hun afzet ondervinden. Voor een juiste verbijzondering van de capaciteitskosten - zo heb ik destijds betoogd - is bij deze bedrijven de kennis van de structuur van de afzet noodzakelijk teneinde de vraag te kunnen beantwoorden, welke afnemers door de ongelijkmatigheid van hun vraag de overcapaciteit doen ontstaan en daardoor voor de kosten van deze overcapaciteit verantwoordelijk zijn.

In mijn „Leer van de Kostprijs" heb ik een aantal structuurvormen onderscheiden, die tot vier methoden leiden voor de verbijzondering van de capaciteitskosten, gebaseerd op de kritische oorzaak van het ontstaan van de seizoensovercapaciteit. Deze oorzaak kan worden gezocht bij:

1. de top- én basisafzet tezamen, waarbij de kosten van de overcapaciteit gelijkelijk over de afzet worden omgeslagen, zodat alle afnemers een gelijk aandeel in de capaciteitskosten dragen,

2. de topafzet, waardoor de kosten van de overcapaciteit geheel ten laste komen van de afnemers die uitsluitend in het seizoen afnemen.

3. de maximum-afzet in het seizoen, waardoor de volle last van de capaciteitskosten op dit deel komt te vallen en buiten het seizoen differentieel kan worden gecalculeerd,

4. top- én basisafzet, waarbij in tegenstelling met de eerste methode beide delen van de afzet een eigen aandeel hebben te dragen overeenkomstig hun aandeel in de maximum-belasting.

In de onderhavige discussie richt zich de aandacht op de tweede en vierde methode. In mijn analyse heb ik ter illustratie van de vierde situatie het elektriciteitsbedrijf gekozen dat als een sprekend voorbeeld van een bedrijf met seizoenafzet en daarmede samengaande seizoenmatige produktie kan worden beschouwd. De heer Winselaar brengt in zijn artikel het gasbedrijf naar voren, waarvan het zelfde kan worden gezegd. Schrijver is ertoe gekomen om datgene wat ik bij wijze van casus omtrent het elektriciteitsbedrijf heb geschreven op het voorbeeld van het gasbedrijf van toepassing te verklaren.

Hier ligt de oorsprong van het - naar zal blijken schijnbare - meningsverschil.

$\mathrm{m}$ a b blz. 323 
De vergelijking gaat niet op als gevolg van de omstandigheid dat tussen de afzetstructuur in beide voorbeelden een principieel verschil bestaat. In het geval van het elektriciteitsbedrijf wordt de afzet gevormd door groepen van afnemers met een naar tijdstip en omvang verschillend beslag op de spitscapaciteit. In het voorbeeld van het gasbedrijf, zoals de heer Winselaar dit stelt, is sprake van twee gescheiden afnemersgroepen, waarvan de één een seizoenvraag heeft (verwarmingsgas), terwijl de andere categorie (de afnemers van het kookgas) een relatief constante afzet waarborgt. Schrijver past nu op dit laatste voorbeeld mijn vierde methode toe, waarbij - zoals boven aangegeven - de afnemers van de top- en basisafzet overeenkomstig hun aandeel in de maximum belasting in de capaciteitskosten hebben bij te dragen. Deze methode geldt, gezien de structuur van de afzet, wél voor het elektriciteitsbedrijf, daarentegen niet voor de geschetste afzetstructuur bij het gasbedrijf. Daarbij past de tweede door mij voorgestelde methode, die tot dezelfde uitkomst leidt als de oplossing die de heer Winselaar in zijn artikel heeft gegeven. De kritische oorzaak van het ontstaan van de overcapaciteit ligt bij de seizoenvraag naar verwarmingsgas, waardoor de kosten van de overcapaciteit ten laste van deze groep van afnemers komt. Ik laat daarbij de vraag buiten beschouwing, aangezien de heer Winselaar daarop niet is ingegaan, hoe het verbruik van verwarmingsgas per verbruiker zal kunnen worden gemeten.

Het misverstand t.a.v. de interpretatie van mijn zienswijze meen ik te moeten toeschrijven aan het feit, dat schrijver zich heeft gebaseerd op de eerste druk van mijn boek, die van 1947 dateert. Daardoor is hem de meer gedetailleerde uitwerking ontgaan, die ik in latere drukken van dit boek van de betreffende problematiek heb gegeven. Reeds in de derde druk, welke in 1953 uitkwam, heb ik het punt, waarover thans de discussie gaat, nader toegelicht. In de laatste editie (die onder de gewijzigde titel „Kosten en Kostprijs” onlangs verscheen) merkte ik aangaande de situatie op, dat bij de tweede methode het bedrijf a.h.w. wordt beschouwd als een combinatie van twee min of meer afzonderlijke bedrijven, die elk een eigen afzet hebben. Wij citeren (blz. 430): „De scheiding die hiermede in de afzet wordt gemaakt, kan zijn die in twee groepen afnemers, nml. een groep die uitsluitend in het seizoen afneemt en een groep van geregelde afnemers, die gedurende het gehele jaar het produkt betrekt, dan wel twee groepen van produkten, waarvan één geregeld wordt afgenomen en het andere een seizoenartikel is". Ik deed daarop als conclusie volgen dat bij zulk een situatie elk van de beide groepen - hetzij van afnemers, hetzij van produkten - zijn eigen capaciteitslasten zal hebben te dragen, een uitspraak gelijk aan die waartoe de heer Winselaar hierboven komt.

Zoals gezegd, heb ik de beschouwingen van de heer Winselaar met belangstelling gelezen; het zij mij veroorloofd te zeggen dat de kritiek die daarin ligt besloten, langs mij heengaat.

H. J. van der Schroeff 